\title{
Da representação à perspectivação de(s)colonial do conhecimento: a ontologia informacional sob a tez ameríndia
}

\author{
From representation to the perspective of de(s)colonial \\ knowledge: the informational ontology under the \\ amerindian skin
}

Vinícios Souza de Menezes a,*

\begin{abstract}
RESUMO: O texto se move através do debate da ontologia da informação e dos estudos indigenistas ameríndios. Dentro desta geografia conceitual, o texto aborda três questões centrais: i) a representação do conhecimento, ii) a perspectivação multinaturalista do conhecimento e iii) a decolonialidade. A representação do conhecimento é analisada por meio da ontologia informacional e seus gestos ontológicos de exclusão, seja em Platão e a expiação dos dessemelhantes, em Aristóteles e a exceção da univocidade decisão do sentido até a Modernidade e a realização dos contornos da metafísica da colonialidade e da colonialidade da metafísica. A partir desta estância americanista propõe-se uma perspectiva de(s)colonial da informação. Sob a tez ameríndia apresenta elementos de perspectivação do conhecimento como uma alternativa anarqueológica de alteração radical dos regimes coloniais de captura dos seres, dos saberes e dos poderes. Por fim, perante os argumentos acionados, manifesta de modo propositivo o informe como uma diferença informacional para desver o mundo em novas coisas de ver, uma tarefa de perspectivar em saberes, outros seres. Nas dobras do corpo ameríndio, a pele de outros mundos germina uma filosofia da informação outra outra. Encontrar as veredas do que está em vias de brotar é a contraconduta de(s)colonial do texto.
\end{abstract}

Palavras-chave: Representação do Conhecimento; Perspectivismo Ameríndio; Multinaturalismo; Ontologia da Informação; Decolonialidade.

ABSTRACT: It deals with the debate on the ontology of information and the indigenous studies of Amerindian thought. It addresses three central issues: i) the representation of knowledge, ii) the multinaturalist perspective of knowledge and iii) decoloniality. The representation of knowledge is analyzed through informational ontology and its ontological gestures of exclusion, whether in Plato and the atonement of the dissimilar, in Aristotle and the exception of univocity decision of meaning, until Modernity and the realization of the contours of the metaphysics of coloniality and the coloniality of metaphysics. From this Americanist vision, a decolonial perspective of information is proposed. Under the Amerindian complexion, there are elements of perspective of knowledge, as an alternative anarchological to change the colonial regimes of capturing beings, knowledge and powers. Finally, there is the propositional suggestion of the formless as an informational difference to unveil the world into new things to see, a task of looking into knowledge, other beings. In the folds of the amerindian body, the skin of other worlds germinates one philosophy of information another another. Finding the paths of what is about to emerge is the text's decolonial counter-conduct.

Keywords: Knowledge Representation; Amerindian Perspectivism; Multinaturalism; Information Ontology; Decoloniality.

\footnotetext{
a Departamento de Ciência da Informação, Universidade Federal de Sergipe, São Cristóvão, SE, Brasil.

* Correspondência para/Correspondence to: Vinícios Souza de Menezes. E-mail: menezes.vinicios@gmail.com.
}

Recebido em/Received: 30/06/2021; Aprovado em/Approved: 06/10/2021.

Artigo publicado em acesso aberto sob licença CC BY 4.0 Internacional @(i) 


\title{
ASSUMIR FORMAS MIL: UMA PERSPECTIVA DE(S)COLONIAL DO INFORMAR
}

\begin{abstract}
A novidade / Que tem no Brejo da Cruz / É a criançada / Se alimentar de luz / Alucinados / Meninos ficando azuis / E desencarnando / Lá no Brejo da Cruz. / Eletrizados / Cruzam os céus do Brasil / Na rodoviária / Assumem formas mil / Uns vendem fumo / Tem uns que viram Jesus / Muito sanfoneiro / Cego tocando blues / Uns têm saudade / E dançam maracatus / Uns atiram pedra / Outros passeiam nus. / Mas há milhões desses seres / Que se disfarçam tão bem / Que ninguém pergunta / De onde essa gente vem / São jardineiros Guardas-noturnos, casais / São passageiros / Bombeiros e babás / Já nem se lembram / Que existe um Brejo da Cruz / Que eram crianças / E que comiam luz. / São faxineiros / Balançam nas construções / São bilheteiras / Baleiros e garçons / Já nem se lembram / Que existe um Brejo da Cruz / Que eram crianças / E que comiam luz.
\end{abstract}

Chico Buarque de Hollanda, Brejo da Cruz (1984).

O pensamento decolonial surge, ao lado dos estudos descoloniais e pós-coloniais, como crítica ao colonialismo. A decolonialidade tem como propósito apresentar alternativas à descolonização do pensamento sugeridas pelos sujeitos colonizados e racializados pelo lado obtuso da Modernidade (Dussel 1993; Maldonado-Torres 2008; Mignolo 2017). O pensamento descolonial resiste desde a violação da conquista e da colonização das Américas. Os povos ameríndios e da diáspora africana resistiram e, estrategicamente, a despeito de toda violência de diferentes magnitudes, disseminaram seus saberes de modo cifrado nos símbolos ocidentais ou no interior das redes de proteção social de suas comunidades. Ocultos ou furtivos nas frestas das malhas do conhecimento ocidental, o pensamento descolonizador latino-americano subsistiu e resistiu até então aos avanços sistêmicos do pensamento colonizador, com muitas perdas irreparáveis, mas com a astúcia, a força e a sabedoria de seguir dos saberes ancestrais. O pensamento decolonial surge como um esforço autoorganizado, multiverso e propositivo dos saberes colonizados ao pensamento colonizador, mirando desfazer das sociedades modernas as colonialidades fixadas no corpo das estruturas sociais do Ocidente.

Os estudos decoloniais compartilham um conjunto sistemático de enunciados teóricos que revisitam a questão do poder na modernidade. Esses procedimentos conceituais são: 1. A localização das origens da modernidade na conquista da América e no controle do Atlântico pela Europa, entre o final do século 15 e o início do 16, e não no lluminismo ou na Revolução Industrial, como é comumente aceito; 2. A ênfase especial na estruturação do poder por meio do colonialismo e das dinâmicas constitutivas do sistema-mundo moderno/ capitalista e em suas formas específicas de acumulação e de exploração em escala global; 3. A compreensão da modernidade como fenômeno planetário constituído por relações assimétricas de poder, e não como fenômeno simétrico produzido na Europa e posteriormente estendido ao resto do mundo; 4 . A assimetria das relações de poder entre a Europa e seus outros representa uma dimensão constitutiva da modernidade e, portanto, implica necessariamente a subalternização das práticas e subjetividades dos povos dominados; 5. A subalternização da maioria da população mundial se estabelece a partir de dois eixos estruturais baseados no 
controle do trabalho e no controle da intersubjetividade; 6. A designação do eurocentrismo/ocidentalismo como a forma específica de produção de conhecimento e subjetividades na modernidade (Quintero, Figueira, Elizalde, 2019, p. 5).

O pensamento decolonial eclode no momento insurreto das guerras pela libertação colonial, das lutas pelos movimentos civis - negro, feminista, homossexual e seus desdobramentos (LGBTQIA+), dentre outros -, da revolução cultural do fim dos anos 1960 e do nascimento do pensamento pós-estruturalista. Ao lado dos studies ${ }^{1}$, o pensamento decolonial compõe a pauta crítica da transvaloração das questões de identidade e diferença que configuram os contornos ontológicos do pensamento ocidental. Seguindo esta linha, Ronald Day (2005) escreve o texto Poststructuralism and Information Studies, o qual insere as questões informacionais no corpo do pensamento pós-estruturalista e dos studies. Todavia, as questões decoloniais do pensamento ameríndio, africano e afro-americano não estão perspectivadas no texto panorâmico de Day. Deste modo, este texto visa associar as questões impulsionadas pelo Projeto Modernidade / Colonialidade / Decolonialidade (MCD) (Escobar 2005) e pelo giro decolonial latino-americano (Castro-Gómez, Grosfoguel 2007) às questões pós-estruturalistas e dos information studies anunciadas por Ronald Day. Dentro das propostas decoloniais, este texto tem como foco particular apontar alguns efeitos coloniais na formação do pensamento informacional, oriundo da ontologia fundamental do Ocidente e, como alternativa reflexiva, assinalar para as veredas propositivas do movimento indigenista brasileiro que verte do pensamento ameríndio e germinam uma perspectiva transformacional do informar.

Sob este sentido, este texto está inscrito em uma anarqueologia da informação, uma contraconduta à colonialidade do poder (Quijano 1991; 2000; 2007), do saber (Lander 2000), do ser (Mignolo 1995; Maldonado-Torres 2007), da natureza (Escobar 2005; Lander 2002; Alimonda 2011), de gênero (Palermo 2006; Curiel 2007; Lugones 2008; Segato 2010), dentre outras colonialidades impregnadas nas estruturas sociais. A anarqueologia dos saberes é a abordagem suscitada por Michel Foucault (2011) para mostrar os efeitos das práticas de governo no plano discursivo dos regimes de verdade, tornando evidentes os processos históricos pelos quais elementos de sujeição foram indexados na produção do governo dos vivos. A análise anarqueológica aborda os efeitos simbólicos da violência na ordem da razão, pensa a força no plano da linguagem e seus processos de conversão nos sistemas de organização do conhecimento. Maria Nélida González de Gómez (2012) argumenta que contemporaneamente os regimes de verdade, fonte analítica da anarqueologia dos saberes, sofreu uma mudança em seus estatutos epistêmicos, passando a configurar-

\footnotetext{
${ }^{1}$ A constelação dos studies contextualiza-se na questão pós-estruturalista. Bem ampla, esta constelação atende, por exemplo, aos cultural studies, media \& communication studies, gender studies, subaltern studies, postcolonial studies, governmentality studies, dentre outros. Ronald Day associa o campo informacional à constelação dos studies a partir do texto de revisão: Poststructuralism and Information Studies (2005), contudo, por exemplo, os aspectos ameríndios do "sul Global” permaneceram ausentes desta revisão. O presente trabalho faz uma tentativa de inclusão do pensamento ameríndio no horizonte dos studies, através do eixo da antropologia informacional pós-estrutural.
} 
se como regimes de informação. Deste modo, levando em consideração o estatuto (des)informacional dos regimes vigentes, uma estória anarqueológica da informação consiste em recusar previamente a obrigação e a força de coação que os instrumentos de representação, sob a insígnia da forma, imprimem sobre os vivos. Neste sentido, a anarqueologia da informação visa desenraizar radicalmente a forma da informação. Seguindo os argumentos de Nildo Avelino (2011) a respeito da posição analítica da anarqueologia, argumentamos que a anarqueologia informacional é um ato de transgressão ao poder ontológico e colonial de dar a forma a algo. A anarqueologia informacional é um "ato de desobediência como ponto de partida e condição de análise" (Avelino, 2011, p. 24), onde a desobediência epistêmica é uma opção decolonial (Mignolo 2008) e a diferença informacional - o informe (Menezes 2018a) -, um modo diferentemente humano de colocar-se no mundo perante a diferença radicalmente outra.

Portanto, assumir a condição proteiforme dos seres informes (Didi-Huberman 2013), as subjetividades colonizadas e racializadas pelos desenhos da metafísica da colonialidade e efetivados pela colonialidade da metafísica e seus colonialismos, é tomar para si as formas mil do outro colonial arquetípico do Brejo da Cruz, musicadas em nossa epígrafe. Há milhões desses seres que se disfarçam tão bem. Trata de dar aspecto a esses seres invisibilizados nas rasuras dos sentidos oficiais do Ocidente. As cartografias decoloniais buscam redimensionar os contornos ontológicos obliterados e reconhecer, nas relações do diferente com o diferente, a consistência humana dos planos info-comunicacionais dos condenados (damnés), como sugeriu Frantz Fanon (1968). Este é o horizonte que marca com as trevas do presente as tintas deste texto.

Figura 1. Cartographies 1. La crise de la dimension.

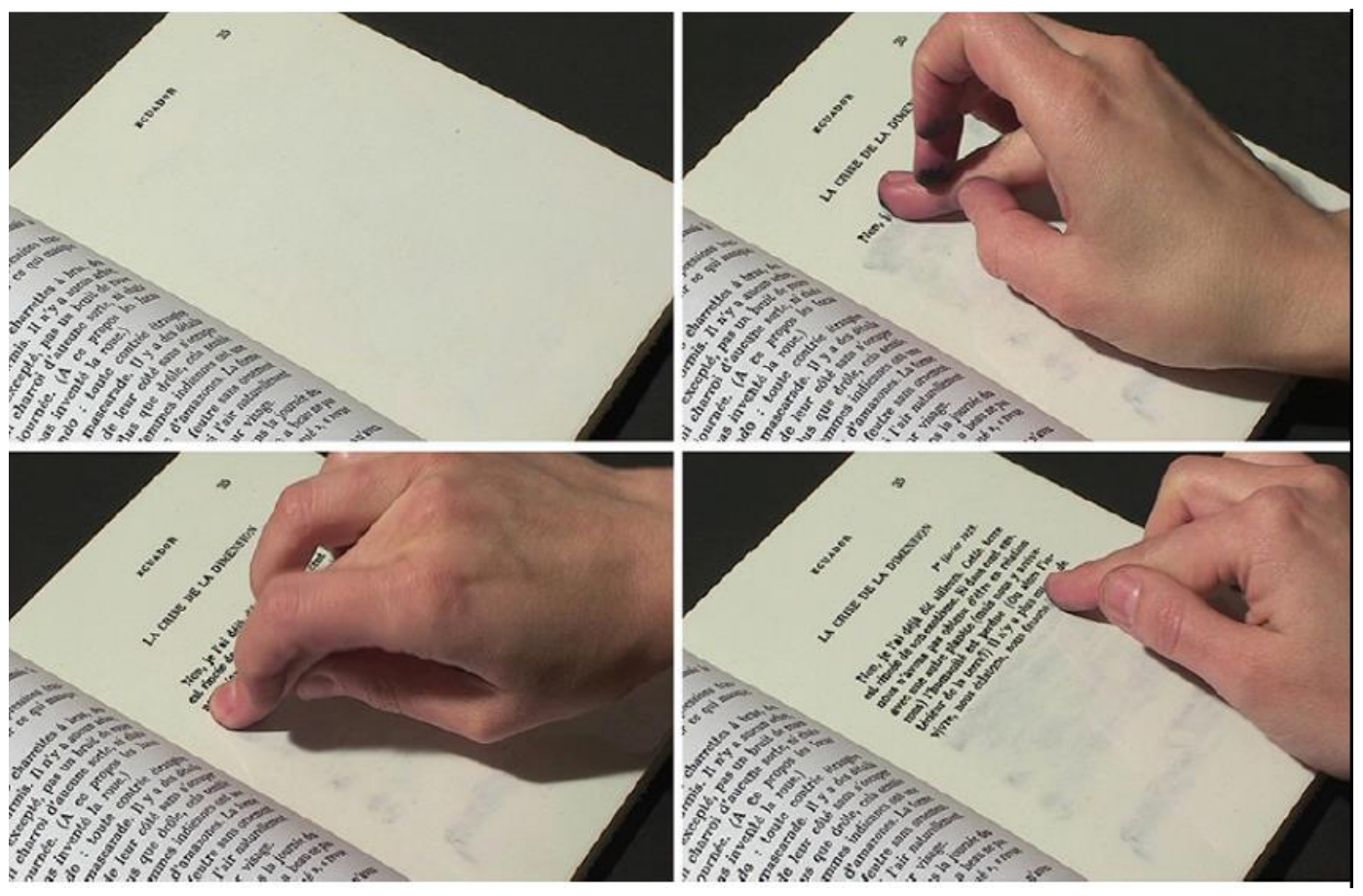

Fonte: Estefanía Peñafiel Loaiza (2010). 


\title{
ONTOLOGIA INFORMACIONAL E REPRESENTAÇÃO DO CONHECIMENTO
}

\begin{abstract}
O que deve ser fundado é a pretensão da representação de conquistar o infinito, a fim de que deva a filha apenas a si própria e se apodere do coração da diferença. Não é mais a imagem que se esforça por conquistar a diferença tal como ela parecia originariamente compreendida no idêntico; é a identidade, ao contrário, que se esforça por conquistar o que ela não compreendia da diferença. Fundar já não significa inaugurar e tornar possível a representação, mas tornar a representação infinita. [...] Esta não é a identidade, mas o meio de subordinar ao idêntico e às outras exigências da representação o que lhes escapava da diferença no primeiro sentido. [...] Fundar é sempre fundar a representação.
\end{abstract}

Gilles Deleuze, Diferença e Repetição (2006, p. 378-379).

A origem latina da palavra informação guarda uma controvérsia poucas vezes acionada pelas hermenêuticas ocidentais e sua rede de sinonímias (typos, eidos, idea, morphé). Conforme a tradição greco-latina legou ao pensamento do Ocidente, informação (informatio) é canonicamente um ato de dar a forma a algo. A tradução latina do termo "forma" encontra no mundo grego a sua expressão histórica, ao menos em dois momentos-chave: i) na eidos (teoria platônica das ideias) e ii) na ousía (ontologia aristotélica), como apresentado por Rafael Capurro e Birger Hjørland (2007).

Esta formulação ontológica estabilizada nos discursos e dicionários ocidentais marca um movimento, de fora para dentro, que marca as operações da metafísica da colonialidade: uma impressão da forma ativa na passiva matéria. A forma modelar informa a matéria determinando-a e, ao determinar o indeterminado, funda materialmente as formas da representação: a identidade no conceito (ratio cognoscendi), a oposição no predicado (ratio fiendi), a analogia no juízo (ratio essendi) e a semelhança na percepção (ratio agendi) (Deleuze, 2006, p. 365-381). Capturada pelas determinações da representação - o idêntico, o semelhante, o análogo e o oposto -, toda razão alterante que escape a esses princípios, deixa de ser pensada e dissipa-se socialmente na categoria do não-ser, o sem forma. O informis é a face oculta da ontologia da informação (informatio) condenada à barbárie do esquecimento na máquina antropológica do Ocidente (Agamben 2011). A formulação da ontologia informacional da Antiguidade sobrevive e renova-se², em seu uso moderno, através do significado predominante da epistemologia e do conceito de representação³.

A virada cognitivista inscrita na teoria do conhecimento e na epistemologia moderna configura, através das práticas de representação, a dialética da colonização. Seguindo a argumentação de González de Gómez (2002, p. 27), a abordagem representacional

\footnotetext{
${ }^{2}$ Os conceitos de sobrevivência e renovação fazem parte da abordagem historiográfica de Aby Warburg (2013).

3 “O conceito de representação remete a algo (o representado) que tem um modo de ser que Ihe é próprio, mas que, não sendo acessível no modo da presença, por estar ausente 'aqui e agora' ou por outra razão, se re-apresenta, num modo diferente de manifestação (a representação)" (González de Gómez, 2002, p. 27).
} 
terá o papel de inserir a informação nas esferas subjetivas do humano, do conhecimento e da linguagem. $O$ conhecimento representa o mundo externo e seus objetos (representation by knowledge), assim como representa a si mesmo (representation of knowledge) através das estruturas mentais, das formas de expressão (visuais, auditivas, táteis), dos artefatos culturais (signos, sinais, códigos) e das ações intersubjetivas. O sujeito informacional é mediado por um sistema de categorias ou conceitos que fundam o modelo de seu mundo e infinitamente desdobra-o, impondo ao outro diferente, o sentido representacional do "hombre imperial" (Maldonado-Torres, 2007, p. 134). No contexto das sociedades colonizadas, o "próprio" e o "autêntico" que se manifestam a todo instante são representações da atitude imperial do ego conquiro, que seguidamente atesta a sua suposta superioridade epistêmica sobre o que julga, de modo misantrópico, como incompleto e inacabado (Gordon 2000). Colonizar é uma ação que parte de uma situação transitiva de incompletude da dessemelhança à ideia, da potência ao ato, da natureza à cultura, do animal ao humano, da barbárie à civilização, da periferia ao centro e o colonialismo, produto da colonialidade da metafísica, é um movimento de imposição de um agente imperial - a forma - sobre algo indeterminado - o sem forma - transformado em objeto - os selvagens sujeitos colonizados e racializados (seres informes). A colônia é o espaço que se está ocupando (terra, povo, objetos ou subjetividades) e que se deve sobre ele agir dominando e governar sujeitando ${ }^{4}$.

A representação, nos diz Deleuze (2006, p. 367), tem "necessidade de um mundo convergente, monocentrado", onde o "idêntico possa reinar sobre o infinito" e que o "infinito seja penetrado pela continuidade da semelhança”. A representação visa integrar e subordinar infinitamente em seus projetos de ilusão transcendental a diferença e seus planos de imanência. Ou seja, em outras palavras, a representação é um operador ontológico informacional de colonização. Chamo de metafísica da colonialidade este desenho aspectual da ontologia da efetividade ocidental ${ }^{5}$. Neste sentido, discordamos da tese geral que a teoria da colonialidade e da $\mathrm{de}(\mathrm{s})$ colonialidade é uma questão historicamente moderna e implementada a partir do século 15, com a invasão de Abya Yala e os consequentes genocídios, epistemicídios e totalitarismos coloniais. A metafísica da colonialidade já se encontrava formulada e em operação nos mundos escravocratas greco-romanos que formaram a base canônica do pensamento ocidental. O mau encontro ocorrido nos litorais de Abya Yala, a partir do século 15, deflagrou a renovação das práticas da colonialidade da metafísica, sob a insígnia histórica das relações capitalistas, da divisão social do trabalho e da ideia de raça. Como afirmou Enrique Dussel (1996), com a Modernidade, o “bárbaro” adquiriu

\footnotetext{
${ }^{4}$ Agir dominando e governar sujeitando são duas ações que indicam a continuidade, circunstancialmente renovadas a partir dos contextos históricos, das duas ontologias que configuram o pensamento ocidental: i) a ontologia da efetualidade (ofício) e ii) a ontologia da operatividade (comando) (Agamben 2013).

${ }^{5}$ A expressão "metafísica da colonialidade" é uma ressonância da crítica dos fundamentos metafísicos do colonialismo, assim como a "colonialidade da metafísica" guarda relação com a crítica dos fundamentos colonialistas da metafísica, ambas, críticas articuladas por Eduardo Viveiros de Castro (2012, p. 155).

${ }^{6}$ Abya Yala ou Terra Viva, expressão de autodesignação do povo Kuna para o continente americano.
} 
novas conotações, tornou-se um sujeito colonizado e racializado. A sobrevivência secular da arkhé (ontologia da efetividade) e do nomos (ontologia do comando) da metafísica ocidental fundou a representação das colonialidades e dos colonialismos da modernidade. Sob as circunstâncias do Novo Mundo, o Velho Mundo instaurou o seu projeto colonial de exceção e naturalizou as violências de suas condutas não-éticas de guerra (Maldonado-Torres 2007) em território hostil à representação e suas faces homogêneas. O olho do colonizador não tolera a constituição do diferente (Bosi, 1992, p. 62).

Sentença por excelência da ontologia informacional, dar a forma algo é uma das faces políticas do projeto metafísico e colonial do Ocidente. A ontologia fundamental inaugura o pensamento informacional e funda a representação. Dar a forma a algo é uma formulação primaz da filosofia da representação - da submissão da diferença à identidade. A articulação entre a ontologia, o pensamento informacional e a representação efetua-se a partir do estabelecimento do pensamento informacional pela ontologia fundamental. $\mathrm{O}$ ato de informar introduz a impressão do modelo ideal de sentido sobre a multiplicidade das disposições histórico-contextuais. A medida de reconhecimento ontológico passa a ser um gradiente de semelhança com a forma, por exemplo, em termos neoplatônicos de classificação dos seres, o homem é a imagem e semelhança de Deus, ou, sob a perspectiva da representação do conhecimento, faz sentido e é válido o conhecimento que se objetiva ao abrigo das operações significativas do sujeito moderno ocidental. Aos dessemelhantes é legado a conversão ritualística, a adequação cultural ou os desígnios altericidas coloniais: genocídios, epistemicídios, ecocídios e outros totalitarismos associados à dimensão representacional do sentido que dá a forma às relações sociais de dominação. Representar é tornar sempre e mais uma vez presente os dispositivos informacionais da ontologia ocidental e suas expressões coloniais. Vejamos dois momentos-chave de formação deste pensamento e da sua aplicação colonial pelos sujeitos imperiais do povo universal.

\section{Platão e a expiação dos dessemelhantes}

Vai aos campos! [Crátilo]; Hermógenes te fará companhia.

Platão, Crátilo (1988, §440e, p. 177).

Um dos registros inaugurais da representação do conhecimento nasce no platonismo, em especial, no método platônico de divisão do mundo. O mundo platônico é uma composição de distinções: essência e aparência, inteligível e sensível, original e cópia, ideia e imagem. A possibilidade de conhecer a inteligibilidade da coisa é uma condição ontológica da partilha da forma (eidos), ou seja, da ontologia do informar (Menezes 2015). Os inteligíveis dão a forma a algo e os elementos sensíveis, ao receberem a ação da ideia, são apanhados pela dádiva da fundamentação, logo, são instituídos politicamente como "boas cópias" (eidolon), representantes sensíveis da ideia. Esplêndidas aparências e bem fundamentadas, os seres sensíveis são a imagem e 
semelhança da Ideia. A tarefa da ontologia informacional platônica é alçar ao sublime a linhagem dos semelhantes (Deleuze, 2006, p. 368-374).

Contudo, há um terceiro elemento em cena: o Devir e seus fantasmas. Entre o mundo inteligível e o mundo sensível há um mundo obscuro, ilegítimo e de inteligibilidade bastarda (khóra), diz-nos Platão (1992, §50c-52b, p. 202-204). Entre a ideia (modelo) e as imagens (cópias), há os fantasmas (phantasmatas), ou, as “más cópias" - imagens sem semelhança, um puro devir sem medida que escapa da ação da forma. Essas “outras aparências" são classificadas como simulacros malignos, perversos e insinuantes, pois não respeitam nem o fundamento, nem o fundado, são informes, não suportam a prova da cópia, nem a exigência do modelo. O platonismo demarca um gesto de exclusão ontológica na pólis, onde a ontologia informacional é uma juíza cujo critério seletivo entre as boas e as más cópias representa a separação entre os seres que estão habilitados a receber a forma - os seres inteligíveis, também conhecidos como humanos $^{7}$ - e aqueles "outros seres", privados da forma e desterrados à condição de não-humanidade dos fantasmas - macrotermo platônico para todos os seres informes, excluídos da República. Este pensamento platônico expressa a vontade ontológica de exorcizar, excluir e reprimir os simulacros da pólis, os dessemelhantes ${ }^{8}$. Em outras palavras, o simulacro é a diferença, a imagem demoníaca destinada à expiação, o desclassificado não-ser, que, com a Modernidade, será vinculado ao liame injusto da subordinação da diferença ao negativo. A tarefa da representação é informar a ideia, dar às coisas um fundamento, um aspecto e uma forma capaz de ser identificada para assim excluir, eliminar e barrar toda e qualquer pretensão de diferença (Deleuze, 2006, p. 369). O ato de dar a forma algo é uma relação de força que visa reduzir o pensamento da diferença à identidade, o informe outro ao ideal informacional do patriarca, o homem livre ocidental e seus patrimônios culturais.

\section{Aristóteles e o gesto de exclusão ontológica da decisão do sentido}

Há impossibilidade 'de que o mesmo pertença e não pertença ao mesmo segundo o mesmo' desde que o adversário simplesmente diga algo; e se ele não diz nada, é ridículo procurar o que dizer em resposta àquele que não sustenta discurso sobre nada, na medida em que, em função disso, ele não sustenta nenhum discurso; pois

\footnotetext{
$7 \mathrm{Na}$ época platônica, os humanos da pólis eram os homens livres, como formulará posteriormente Aristóteles. Todavia, em Platão, são humanos plenos os aristocratas e, por vezes, sob condições específicas, os metecos - classe de artesãos, comerciantes, estrangeiros admitidos na pólis, dentre outros grupos que estavam entre a classe aristocrática e os escravos. Desta maneira, dentro do gradiente de humanidade formulado pela democracia grega, os cidadãos eram os humanos plenos, uma parcela diminuta de homens livres, autorizados a conduzir as transações da pólis. Para uma consideração a respeito, conferir Platão $(2017, \S 563 a$, p. 394).

${ }^{8}$ Em Atenas, os humanos inteligíveis ao serem convencidos ou persuadidos por educadores e sofistas, classe de indivíduos classificados socialmente como dessemelhantes, poderiam ser castigados com a morte ou com a atimia, um dispositivo "republicano" de privação total ou parcial dos direitos de cidadão (Platão, 2017, §492d, p. 280).
} 
um tal homem enquanto tal é de saída semelhante a uma planta [...] Se [...] afirmássemos significar uma infinidade de coisas, é claro que não haveria; pois não significar uma única coisa é não significar nada absolutamente, e se as palavras não significam, destrói-se a possibilidade de dialogar uns com os outros, e na verdade consigo mesmo: pois não se pode pensar em nada sem pensar em algo único, e se o pudermos, colocaremos então uma palavra única sobre essa coisa.

Aristóteles, Metafísica (2002, §1006a-1006b, p. 145-147).

A formulação da epígrafe é conhecida como a "decisão do sentido" aristotélica. O princípio aristotélico da "decisão do sentido" entende a informação como o princípio formal e afirmativo de atualização do sentido. Informar como ato de dar a forma a algo é a ação de falar e gerar algo único, dá-lhe um sentido ou o sentido do um. "Fala, se és homem", nos diz Cassin (1993, p.32), pois, somente o homem livre9 - o anthropos aristotélico - é um gerador de sentido e forma, o único dotado de fala e capaz de exprimir um e só um significado determinado. $O$ signo dessa exclusão essencial é que nenhum animal ou planta "tem a palavra" (aneu logon | alogon pragma) e informar o mundo é uma possibilidade exclusivamente humana, ou, em outras palavras, a representação do mundo é um privilégio privado do patriarca, o cidadão. Esse gesto de exclusão em Aristóteles (2002, §982b 20-28, p. 10-13) funda a filosofia como "única ciência livre" já que "única que é em vista de si mesma" e faz do "homem livre" (anthropos) seu operador por excelência, o único ser "que o é em vista de si mesmo" (ho hautoû héneka). Informar é uma retórica branca colonial de configuração do mundo em vista de si mesmo, conforme os segredos dos seus olhos, a univocidade do seu sentido e a virulência de suas ações. Excluindo aquilo que o torna possível, o sentido é a primeira entidade que não pode tolerar a contradição (Cassin, 2005, p. 96) e o não-contraditório é a essência formal do homem. O sentido é feito de tal modo que algo ou tem sentido ou não é, ou seja, "é da natureza do sentido o fato de ser totalitário, quer dizer, reduzir a si mesmo tudo o que não é ele" (Cassin, 2005, p. 8485).

Não significar uma única coisa é não significar nada absolutamente, é possuir uma vida marginal ao sentido. Dizer que uma mesma palavra aciona mais de um significado em seu plano de significação é privar esta palavra de um sentido, afastá-la da unidade íntima a todo sentido, conforme Aristóteles. Caso fale multiplicidades, em pura perda, ou não seja dotado de existência discursiva, como um pária ou um marginal, e só lhe "reste" corpo e matéria como mulheres, estrangeiros, escravizados, animais, monstros, sofistas, bárbaros e indígenas, és um ser informe, um não-humano fora do sentido (Cassin 2017). As vidas marginais dos seres informes balbuciam um "discurso impuro, bastardo e híbrido" e "tomam para si todos os perigos que esta [fala] deve enfrentar, todas as condenações, perseguições e denegações que ela sofre” (Deleuze, Guattari, 1992, p. 57).

9 Para as questões de gênero implicadas nesta formulação aristotélica, conferir Menezes (2018b). 
Os efeitos da diferença ontológica encontram morada nas formas da política: "la ontología es una filosofía del poder" (Maldonado-Torres, 2007, p. 152). Informes e sem obra, os não-seres são por natureza semelhantes aos escravizados. Fora do sentido humano, a condição colonial de não-ser, não-poder e não-saber é herdeira da teoria aristotélica do escravo natural (Aristóteles, 1988, §1254b, p. 57-59). Epistemicida, o sentido nega a alteridade e a legitimidade dos sujeitos de conhecimento, das maneiras de organização social e dos modos de conhecer do Outro. As partículas negativas do sentido simbolizam aquilo que ocorre não ser, que absolutamente não é, que não pode e não deve ser, pois não possui um "aí" - trata-se de um nada existencial (ouk on). À diferença do homem ontologicamente significativo, o mundo maniqueísta do Ocidente produz o seu simetricamente oposto, o humano sem obra (argos), ou, cuja obra não diz respeito aos caracteres distintivos da humanidade. Este humano outro, em negativo, semelhante às plantas e aos animais, na estrutura social e política da metafísica da colonialidade está representado pela escravidão natural formulada por Aristóteles. Decaído à condição informe, a obra imperfeita do escravizado é o "uso dos corpos" (he tou somatos chresis). Fora do nous, a obra do escravizado é não-humana (ergon doulou), enquanto a do homem livre, reafirma a sua exclusividade senhorial (ergon anthropou) de informar. A alma comanda o corpo com um comando despótico, enquanto o intelecto comanda o apetite com um comando político. Em outras palavras, a alma está para o corpo assim como o senhor está para o escravo. Neste ente escravizado, o corpo encontra-se em uso, enquanto no homem livre, a alma está em obra segundo a razão (Aristóteles, 1988, §1254b, p. 57-59). Em termos modernos, a partir do pensamento cartesiano, a colonialidade do ser atualiza-se na dúvida misantrópica, isto é, no ceticismo da condição de humanidade dos sujeitos colonizados, despossuídos de pensamento, como argumenta Maldonado-Torres (2007, p. 144):

\footnotetext{
Debajo del 'yo pienso' podríamos leer 'otros no piensan', y en el interior de 'soy' podemos ubicar la justificación filosófica para la idea de que 'otros no son' o están desprovistos de ser. De esta forma descubrimos una complejidad no reconocida de la formulación cartesiana: del 'yo pienso, luego soy' somos llevados a la noción más compleja, pero a la vez más precisa, histórica y filosóficamente: 'Yo pienso (otros no piensan o no piensan adecuadamente), luego soy (otros no son, están desprovistos de ser, no deben existir o son dispensables).
}

Sob estes marcos substanciadores, a ontologia informacional chega na Modernidade. O mundo quinhentista da invasão de Abya Yala tinha em Aristóteles seu patrono. Contudo, em termos modernos, a ontologia dissolveu seus pressupostos nos argumentos epistemológicos da teoria do conhecimento. O ser foi racializado nas dobras das subjetividades modernas e o mundo da physis objetificou-se nas imposturas epistêmicas das explorações e dominações da natureza.

Modernidade: entre a metafísica da colonialidade e a colonialidade da metafísica 
1) convertir la naturaleza y el cuerpo en objetos de conocimiento y control; 2) concebir la búsqueda del conocimiento como una tarea ascética que busca distanciarse de lo subjetivo/corporal; y 3) elevar el escepticismo misantrópico y las evidencias racistas, justificadas por cierto sentido común, al nivel de filosofia primera y de fundamento mismo de las ciencias. Estas tres dimensiones de la modernidad están interrelacionadas y operan a favor de la continua operación de la noética de la guerra en el mundo moderno.

Nelson Maldonado-Torres, Sobre la colonialidade del ser: contribuiciones al desarrollo de un concepto (2007, p. 145).

A partir da insurreição da América Indígena, o campo da Antropologia tem provocado no campo filosófico algumas fissuras ontológicas, ao apontar os problemas enraizados não só na constituição metafísica da colonialidade - "a tipografia do informar" (Menezes 2018b) -, mas, também, na colonialidade da metafísica - "as práticas de colonização do pensamento". Dentro deste projeto de ontologia política, ambas, metafísica da colonialidade e colonialidade da metafísica, são versões da filosofia da representação e a ontologia informacional não seria senão uma artífice de seus instrumentos de representação do conhecimento como, por exemplo, assinalado por Hope Olson (2002) em The power to name: locating the limits of subject representation in libraries, a respeito do poder colonial do nome nos modelos universais de Organização do Conhecimento e a produção de guetos, diásporas e invisibilizações dos sujeitos historicamente subalternizados nos instrumentos de representação temática e descritiva do conhecimento.

Reavivados nos colonialismos pela expressão epistemológica da Modernidade, os elementos ontológicos de dominação e sujeição requeridos para a formação do mundo humano se reatualizam secularmente nos contornos da representação. Enquanto no mundo aristotélico, livre é o homem que o é em vista de si mesmo e não de outro, em Kant, a possibilidade de constituição de um sentido propriamente humano, segundo as faculdades e os limites do conhecimento objetivo, passa pela capacidade de constituir o homem como o único habitante propriamente dito do mundo. Na filosofia transcendental, o mundo é um posto autorreferencial exclusivo do entendimento humano do homem, que o concebe sob a forma superior da sua humanidade. Kant (1986, p. 15-16) argumenta que "o homem é um animal que necessita de um senhor", o qual, porém, nos diz Valentim (2018, p. 160), não pode ser encontrado fora de si mesmo, visto que o sujeito universal é o único cidadão autêntico do mundo ${ }^{10}$. Em Hegel, informar algo no mundo é uma capacidade antropogenética, mediada por condições socioespirituais (mundo real objetivo, não natural, cultural e histórico), que simboliza a libertação do homem da angústia que o ligava à natureza (inata ao animal e sua primitividade). Alexandre Kojève (2002, p. 15) argumenta que a dialética entre senhor e escravo é a "relação social fundamental" e o mundo humano caracteriza-se necessariamente por "um elemento de dominação e um elemento de sujeição,

10 "Todos os progressos na civilização (kultur), pelos quais o homem se educa, têm como meta que os conhecimentos e habilidades adquiridos sirvam para o uso do mundo; mas no mundo o objeto mais importante ao qual pode aplicá-los é o homem: porque ele é o seu próprio fim último (letzter Zweck)" (Kant, 2005, p. 21). 
existências autônomas e existências dependentes". Em Hegel, a transformação de um mundo hostil em um mundo humano, "começa pelo ato de impor-se ao 'primeiro' outro com que se depara” (Kojève, 2002, p. 17).

No território de conhecimento da Documentação, Alex Wright (2014) recorda que por trás da retórica da paz e do internacionalismo, Paul Otlet lutou para conciliar sua altivez pacifista com o colonialismo europeu, em especial, no Congo Belga. Wright (2014) apresenta a defesa de Otlet do projeto do Congo como um empreendimento cristão e humanitário e que os belgas deveriam livrar os africanos de sua longa decadência moral e intelectual. Por mais de uma vez, Otlet declarou ser "um visionário", o Rei Leopoldo II - genocida que dizimou mais de 10 milhões de congoleses no processo de colonização - e caracterizou todo o projeto europeu na África como "uma grande missão civilizadora", uma vez que a colonização fez com que os povos colonizados "apreciassem os benefícios da civilização" (Wright, 2014, p. 152). Dentre outros aspectos do sujeito imperial impregnado no homem Otlet colonizador, Wright (2014, p. 53) ainda revela que o jovem Mayalé, filho de um chefe do Congo, foi sequestrado e escravizado pela família Otlet a partir de 1886. Dissimulado nas pretensões universais do conhecimento objetivo da Modernidade, Paul Otlet fundou a Documentação como um projeto atravessado pela colonialidade do ser, do poder e do saber.

Um outro exemplo de renovação desta máquina de exclusão moderna é o emprego, através das tecnologias de vigilância, da biocolonialidade ${ }^{11}$ do holocausto. A organização maciça da informação e as práticas classificatórias de identificação e localização secularmente aplicadas nos acervos bibliográficos, transforma-se, a partir do nascimento da biopolítica, em ferramentas de controle social e, por conseguinte, em armas de guerra e em manual de orientação para o extermínio em massa. A IBM através da indexação cruzada de seu sistema de classificação de cartões perfurados, inaugura o recenseamento racial e, em 1933, inicia a identificação de judeus (Black 2001). Em outras palavras, a ontologia informacional instrumentaliza nos aparatos de representação do conhecimento biopolítico o seu projeto metafísico. Não se tratava mais de, por meio da representação dos números notacionais, identificar nas estantes a obra bibliográfica procurada. Os números notacionais nas fichas Hollerith ${ }^{12}$ identificavam o lugar, nas redes de ruas e vielas das cidades nazistas - as estantes das estruturas sociais -, onde encontrar o potencial inimigo - analogamente, o condenado livro informe. Nos diz Edwin Black (2001, p. 4): "a distribuição de alimentos era planejada com base nos bancos de dados, de modo a matar de fome os judeus", assim como, a "mão-de-obra escrava era identificada, rastreada e gerenciada principalmente por meio de cartões perfurados." As operações de classificação de cartões perfurados foram implementadas em todos os campos de concentração nazistas e inaugurou, através da racialização das técnicas de recuperação da informação, as tecnologias do genocídio.

\footnotetext{
${ }^{11}$ Sobre a biocolonialidade, conferir Juan Camilo Cajigas-Rotundo (2007) e Yilson J. BeltránBarrera (2019).

${ }^{12}$ Fichas retangulares, com 5 1/4 polegadas de comprimento (13,33 centímetros) e $3^{1 / 4}$ polegadas de largura ( 8,25 centímetros), divididas em colunas numeradas, com orifícios em várias fileiras.
} 
Todos os dias chegavam contingentes de mão-de-obra escrava. Os prisioneiros eram identificados por meio de cartões Hollerith descritivos, cada um com as colunas perfuradas, detalhando nacionalidade, data de nascimento, estado civil, quantidade de filhos, motivo do encarceramento, características físicas e habilidades profissionais. As colunas três e quatro reuniam dezesseis categorias codificadas de prisioneiros, dependendo da posição dos orifícios: o orifício 3 significava homossexual; o orifício 9, anti-social; orifício 12, cigano. Orifício 8 designava judeu. Listas impressas com base nos cartões também relacionavam os prisioneiros por códigos numéricos pessoais.

A coluna 34 era rotulada 'Razão de Partida'. O código 2 simplesmente significava transferido para outro campo a fim de prosseguir com o trabalho. Morte natural era código 3. Execução, código 4. Suicídio, código 5. O agourento código 6 designava 'tratamento especial', termo que em geral significava extermínio, seja em câmara de gás, seja por enforcamento ou fuzilamento (Black, 2001, p. 15).

Se na Antiguidade, a ontologia produzia o humano através da oposição com o animal, por exemplo, o macaco-homem, a criança selvagem, mas também, e sobretudo, "o escravo, o bárbaro, o estrangeiro", figuras de um "animal em forma humana", na Modernidade, excluindo de si como não-ainda ou não-mais humano um já humano, isto é, animalizando o humano, a ontologia produziu o "homem-macaco, o judeu, o cigano, o mulçumano de Auschwitz, o negro, o indígena, o homossexual...", figuras do "animal isolado no próprio corpo humano" (Agamben, 2011, p. 57). Além de uma ilusão da dignidade exclusiva da natureza humana, há i) uma ilusão especista que pressupõe uma humanidade unificada e separada da natureza por sucessivas mutilações evolutivas e ii) uma ilusão racista, onde povos diferentemente humanos, como os ameríndios e os afro-americanos, são segregados da condição humana exclusiva do homem branco - o povo universal. De modo ontocêntrico, como na Filosofia da Informação de Luciano Floridi (2011) ou através da ontologia fundamental heideggeriana ${ }^{13}$ interpretada pela hermenêutica capurriana (1992), a ontologia da informação através do ser-aí histórico-político, agente epistêmico da representação e da modelagem (inforg) e sujeito hermenêutico da interpretação, funda a sua morada no mundo à revelia do dessemelhante não-autêntico ${ }^{14}$. Nestes termos, nos diz

${ }^{13}$ Chamo a atenção especialmente para o que Heidegger (2011) chamou na sua ontologia fundamental de "diferença ontológica". A diferença ontológica está fundamentada na diferença entre entes humanos (ser) e não-humanos (entes) e esta distinção encontra-se desdobrada na seguinte tríade de teses: i) o ente-humano é o ser capaz de compreensão e formação de mundo, ii) dos entes não-humanos, os animais e as plantas são pobres de mundo e iii) os entes inanimados são sem mundo. Logo, o mundo é uma designação do ser-aí humano (dasein) no cerne da sua essência existencial de sentido (ek-sistente). O mundo é um isolamento metafísico exclusivo do humano e o dasein "ente que nós mesmos somos", dirá Heidegger, é essencialmente "em vista de si mesmo" (um seiner selbst willen).

${ }^{14} \mathrm{~A}$ abordagem intercultural de Rafael Capurro mitiga os efeitos da ontologia fundamental de Heidegger, todavia, ainda conserva os traços da diferença ontológica quando em Angeletics: $a$ message theory (Capurro, 2003, p. 69) diz: "a fórmula de Heidegger 'ser-no-mundo' significa ser pragmaticamente inserido numa rede de relações e ser capaz de responder às mensagens que as coisas nos oferecem dentro de situações específicas e de acordo com nossas necessidades específicas. Heidegger chama essa maneira de 'formar o mundo' (weltbildend) em contraste 
Heidegger (1987), o ser é o "destino espiritual do Ocidente" e o seu discurso, a metafísica ocidental, nos mostra Eduardo Viveiros de Castro (2018, p. 27), é a fonte e a origem de toda espécie de colonialismo - interno (intraespecífico), externo (interespecífico), e se pudesse, eterno (intemporal).

Portanto, retornando à controvérsia da palavra informação, temos uma possibilidade latente da diferença, um devir perspectivo fora da unicidade do sentido e da identidade da representação. No Thesauro da Língua Latina (1934, p. 1474-1477), a palavra informatio possui, além da conotação canônica da tradição ocidental (informo), o sentido subjacente da ação de privar ou afastar a forma de algo (informis). O prefixo latino in-, herdeiro do alfa grego ( $\alpha$-), não possui apenas a função copulativa como em dar a forma a algo, mas, diz-nos Emanuel Carneiro Leão (2010, p. 216), a partícula intem por excelência a função de resistência, libertação e desprendimento das formas para a transformação das forças. $O$ informe (informis) é uma força de resistência ao pensamento representacional da ontologia informacional e, por fim, argumentamos que o informe tem no pensamento ameríndio uma possibilidade expressiva de manifestação pragmática.

\title{
ONTOLOGIA DO INFORMAR E PERSPECTIVAÇÃO DO CONHECIMENTO: A TEZ AMERÍNDIA
}

\begin{abstract}
De acordo com os mitos principais [dos Tsimshiam, do sudeste do Alasca, falantes da língua Sm'algyax], o mundo, para o ser humano, tem o aspecto de uma comunidade humana circundada por um domínio espiritual, o que inclui um reino animal onde todos os seres levam a vida de acordo com suas características e interferem na vida dos demais seres. Contudo, se nos transformássemos em um animal - em um salmão, por exemplo -, descobriríamos que a gente salmão é, para si mesma, o que os seres humanos são para nós, e que, para os salmões, nós humanos aparecemos como naxnoq [espíritos], ou talvez como ursos devoradores de salmões. Esse processo de tradução atravessa vários níveis. Assim, por exemplo, as folhas do algodoeiro que caem no Rio Skeena são o salmão da gente salmão. Não sei o que os salmões seriam para as folhas, mas suspeito que são vistas por estas como o somos pelos salmões.
\end{abstract}

Marie-Françoise Guédon, An introduction to the Tsimshian world view and its practitioners (1984, p. 141).

Uma perspectiva não é uma representação porque as representações são propriedades do espírito, mas o ponto de vista está no corpo.

Eduardo Viveiros de Castro, Perspectivismo e multinaturalismo na América indígena (2017, p. 379).

com o mundo dos seres vivos não-humanos como 'pobres do mundo' (weltarm) e aos seres não-vivos como 'sem mundo' (weltlos)". 
O contato com a inconstância da alma selvagem e as variações do corpo vário desconcertou a máquina antropológica do Ocidente. Ao custo dos múltiplos genocídios, epistemicídios e ecocídios, o ato imperial organizou-se através das tentativas de dar a forma ocidental àqueles para quem qualquer forma limitativa deve ser deglutida (abaporu). Nas línguas românicas e suas variações, o informe padeceu da imposição opressora da forma, sendo, enquanto diferença, maculada pela cooptação da identidade e suas operações de representação. Desde o ponto de vista opressor da ontologia informacional do Ocidente, o informe (informis) é a condição daquilo que não tem ou não faz sentido - trata-se antes de uma falta ontológica (sem alma) ou de uma ausência político-cultural (bárbaro). Não ter forma é ser privado da condição de humanidade, ou, como afirmava Aristóteles (2002, §1006a-1006b, p. 145-147) é possuir um logos de planta (homoios phutôi). Entretanto, sob o ponto de vista do oprimido como, por exemplo, o dos povos ameríndios, ser informe é uma condição fora-dosentido e da forma ocidental. Condição libertária de viver perspectivamente com as diferentes humanidades que habitam o cosmos, ser informe é uma multiplicidade que atravessa os modos de vida dos povos ameríndios permeados pelo registro anarqueológico da informação, uma contraconduta das sociedades contra o Estado (Clastres 1979) e seus semelhantes patriarcais. Com traços anárquicos e autogestionários, os povos ameríndios gestam e autodeterminam seus modos informacionais coletivamente, fora da colonialidade dos sentidos e das formas impositivas e seus instrumentos de representação. Por conta das características informes do corpus ameríndio, o devir-América do conhecimento faz-se por perspectivação e não pela representação das imagens do mundo eurocêntrico. O saber informe é uma anarqueologia da informação. Habitar esse ponto de vista é fazer-se humano em devir.

A perseguição dos modos informes de vida dos povos ameríndios foi assumida pela ontologia informacional em seu projeto moderno de colonialidade. No vocabulário da ontologia informacional, segundo o Thesauro da Língua Latina (1934, p. 1474-1477), o informe (sem forma) é o sem enredo - sem história e sem retórica. Nas crônicas logocêntricas da conquista e seus comentários etnocêntricos, o indígena das Américas é descrito como informe - um ser amorfo e sem tradição ${ }^{15}$. Com a colonização e os extermínios da invasão colonial, os dessemelhantes de Abya Yala receberam os estigmas do bárbaro (de língua áspera, balbuciante) e do infame (privado de erudição $)^{16}$. Por seu caráter alheio à cidade, o ameríndio foi tido como um corpo sem espírito (um animal), ou, um idiota - uma pessoa inabilitada a falar na pólis. Em simbiose com a natureza, os povos da floresta foram associados a seres multiformes, metamorfos, bestas deformadas, monstros sem alma (sem a graça de Deus). Os

\footnotetext{
${ }^{15}$ Serafim Leite, eminente historiador da Companhia de Jesus no Brasil, Gabriel Soares de Souza, Alexandre Rodrigues Ferreira, Capistrano de Abreu, dentre outros, são unânimes ao assinalar a inconstância e a "amorfia da alma selvagem" (Viveiros de Castro, 2017, p. 186-188).

${ }^{16}$ Segundo os colonizadores, o gentio brasileiro possuía uma série de ausências fundamentais à condição do humano ocidental. Os ameríndios não possuíam fé, lei e rei, assim como, falavam por meio de sons guturais inarticulados - sem efes ( $f$ ), eles (l) e erres ( $r$ ) - e sem sentido - sem compreensão ou racionalidade. Deste modo, maculado pelo pecado e desprovido de poder, o gentio era herege e marginal por não possuir os hábitos próprios e exclusivos dos homens universais.
} 
jesuítas afirmavam onticamente ser o ameríndio um "homem cera", uma matéria pronta para a impressão de uma forma, efetuada pela catequese. Os ameríndios foram também descritos como selvagens semelhantes às florestas - silvícolas cujas maneiras de ensino e aprendizagem devem ser apagadas. Portanto, os ameríndios são os seres informes da América colonizada. Ao lado de outros povos não-brancos, como os africanos e os afro-americanos escravizados, o informe é aquilo que deve ser reprimido e tornado sem discurso.

Contudo, apesar do mal que aplacou Abya Yala, os seres informes multiplicaram nas marginalias do sentido seus significados emudecidos pela ontologia informacional dos ocidentais. Puseram a linguagem na encruzilhada, perturbaram o estatuto das coisas e, através do "sentido de seu próprio sentido" (Viveiros de Castro, 2002, p. 115), chacoalharam os limites coloniais do saber, do poder e do ser. A tez ameríndia nos apresenta a possibilidade da diferença informe, uma encruzilhada da "ontologia infundamental" (Valentim 2018) na metafísica canibal dos estudos decoloniais da informação. Afinal, não há como representar o que não tem presença, o que não se manifesta aos olhos imperiais do informar. Representar é tornar a coisa ausente, presente, todavia, a coisa ausente, a forma indubitável, não existe nos mundos ameríndios, foi devorada. Sem ausências, os mundos ameríndios são pelo calor de tudo, vivos (hilozoísmo) e irrepresentáveis.

Da representação ao perspectivismo do conhecimento, o mundo ameríndio acessa mundos plurais, múltiplas naturezas. Uma perspectiva não é uma representação. As representações são propriedades do espírito enquanto o ponto de vista está no corpo - "Pensa assim com a carne mesmo" (chinãma keskánã namikasenã), diz o xamã Marubo (Cesarino, 2012, p. 83). Sob uma condição genérica onde a humanidade está disseminada entre todos, a perspectiva ameríndia é uma diferença corporal. Diferente da via ocidental, onde o humano é um gradiente especista fruto de podres poderes, no mundo ameríndio, o humano é uma condição de todos os seres, sendo o corpo a medida da alteridade. O idioma simbólico dos povos ameríndios é a corporalidade da pessoa humana (Seeger, Da Matta, Viveiros de Castro, 1979, p. 3) e o "perspectivismo é um maneirismo corporal" (Viveiros de Castro, 2017, p. 380). Se, nos mundos ameríndios, a cultura é a natureza do sujeito, a natureza é o modo do Outro diferentemente humano enquanto corpo. Trata-se de uma cultura - humana - e múltiplas naturezas - corporais.

Não há diferença ontológica no perspectivismo ameríndio - o ser é uma questão da alteridade perspectivada pelo corpo. Outrem não é nem sujeito nem objeto, nem ser nem ente, mas a relação social absoluta. Este animismo perspectivista encontra-se associado ao multinaturalismo de Abya Yala. Os animais veem da mesma maneira que nós, todavia, coisas diversas do que vemos, porque seus corpos são diferentes dos nossos. Enquanto vemos um lamaçal, o tapir vê um arraial festivo, enquanto vemos sangue, o jaguar vê cerveja, enquanto vemos carniça, o urubu vê carne assada (Viveiros de Castro 2017; 2018). Trata-se de um giro ontológico notabilizado pela contingência dos fundamentos e pela variação do estatuto das coisas. A mudança não concerne à humanidade impregnada no sentido das palavras, mas à humanidade das coisas. $O$ giro 
ontológico assinala para uma libertação do pensamento epistemológico que enclausurou e obliterou, dentro das "suas condições gerais do enunciado legítimo", a possibilidade de uma reflexão ontológica para além dos pressupostos da filosofia da representação (Holbraad, Pedersen 2017). O informe é uma possibilidade da diferença informacional (Mostafa 2013). Parafraseando Deleuze, o informe é um agenciamento em que o diferente se relaciona com a diferença pela própria diferença, um reconhecimento da autodeterminação do discurso do nativo (Viveiros de Castro 2002).

Provocado pelas transformações indígenas da Antropologia, o giro ontológico busca redistribuir simetricamente os valores das categorias do "pensamento", colonizadas pela metafísica da colonialidade ocidental. Este movimento propõe uma transformação geral, uma revisão que visa recolocar questões clássicas acerca das coisas do mundo (o que é que existe?) e dos seus modos de existências (como classificamos o que existe?). Ao desvincular-se do pensamento representacional da teoria do conhecimento, o giro ontológico reposiciona em sua reflexividade, conceitualização e experimentação também as questões informacionais. Sob o ponto de vista ameríndio, a informação como um operador de relação (González de Gómez, 1999, p. 25) é transformacional, um relacionalismo perspectivo entramado por relações sociocósmicas, onde o cosmo é o corpo do mundo que vê e come ${ }^{17}$. Nos grafismos da tez ameríndia estão inscritos amanhãs informacionais que vieram ontem. Uma potência informe grávida de outros mundos possíveis para um mundo ocidental em colapso.

\section{CONCLUSÃO... É PRECISO DESVER O MUNDO}

O que muda quando o sujeito da 'história' não é mais ocidental?

$$
\text { James Clifford (1988, p. 344). }
$$

A gente gostava das palavras quando elas perturbavam o sentido normal das ideias.

Manoel de Barros, Menino do Mato (2010, p. 450).

No início de Menino do Mato, Manoel de Barros (2010, p. 449-450) expressa a vontade de "desver o mundo para encontrar nas palavras novas coisas de ver". A subjetividade da mata entendia que "era preciso desver o mundo para sair daquele lugar imensamente e sem lado". Carecemos de desver os nossos instrumentos de representação do conhecimento que não tematizam as categorias desses outros mundos. Por vezes, nossa crítica até então foi assimilacionista e colonial, uma tentativa de integração do diferente ao aparato identitário da representação, seja pela expansão das categorias sub-representadas ou pela inclusão do outro ao código de si, seja no estabelecimento de individuações de autoria para uma pessoa, que em realidade, são

17 "O perspectivismo ameríndio postula uma visão do mundo, o mundo como visão, mundo feito de olhos - de olhos e de bocas - mundo vidente-canibal, onde tudo que há, vê e come." (Viveiros de Castro, 2012, p. 169) 
muitas, ou, num plano temático dos assuntos, ao estabelecer relações de univocidade terminológica para mundos configurados pela equivocidade e pelas relações de homonímia, anfibolias comutativas e comunicações interespecíficas (Viveiros de Castro, 2018, p. 87-94). No mundo ocidental da Biblioteconomia e da Ciência da Informação, o espelho voltado ao outro tem reiterado o reflexo de si.

A ontologia informe e relacional dos povos ameríndios provoca deslocamentos em nossos modos estruturais de formular as práticas informacionais. Sob o perspectivismo do conhecimento ameríndio, onde não há a diferença ontológica entre seres e entes, não há no plano das classificações razões para uma distinção fundamental entre seres e saberes, informações e documentos (Pombo 1998). Sob a perspectivação do conhecimento ameríndio, a crítica neodocumentalista ao movimento mentalista do cognitivismo altera-se, pois o poder da imagem (Frohmann 1992) entre os povos da floresta não é representacional, mas transformacional, como no conceito de imagem (utupë) descrita n’A queda do céu por Kopenawa e Albert (2015) e a subjetividade nascente é um "devir-outro" não capturado pelas reproduções de ausências do povo da mercadoria. A imagem do pensamento selvagem é um altercognitivismo (Viveiros de Castro, 2018, p. 88). Povoado por elementos corporificados, o cosmos ameríndio é revestido por peles, envoltórios que recobrem todos os componentes do corpo cosmológico. Grande suporte encoberto por camadas diversas, a materialidade do corpo ameríndio conceitualmente imagina todo objeto como uma pessoa e toda coisa é significativa, informacional ao seu modo. Logo, hipoteticamente, o mundo ameríndio é uma bio(biblio)grafia e o livro selvagem ${ }^{18}$ é uma pele de imagens (Kopenawa, Albert, 2015, p. 66).

Portanto, o informe é uma estória anarqueológica do irrepresentável na ontologia da informação. Somente pelos olhos opressores da história oficial é uma estória em negativo. Enquanto diferença perspectiva, o informe é uma potência positiva, fora da representação. Na tez dos corpos ameríndios, o informe vê no objeto de interpretação uma outra pessoa, ou, em outras palavras, sob o multinaturalismo perspectivo, o próprio ato de interpretação pressupõe a condição de pessoa do que está sendo interpretado (Strathern, 2006, p. 380). É uma tarefa porvir, perspectivar em saberes, outros seres, trazer nas dobras do corpo, a pele de outros mundos. Se em relação ao pensamento informacional cognitivo, Frohmann (2004) propôs uma Filosofia da Informação Outra, os povos ameríndios, em relação à ontologia informacional, propõem uma Filosofia da Informação Outra Outra. Na ausculta do menino do mato (Barros, 2010, p. 453), deixemos de lado "as palavras bichadas de costumes" e inauguremos uma "linguagem de primavera". Essas veredas são uma contraconduta de(s)colonial porvir. Encontrar veredas é um acontecimento para os que não andam em linha reta, nos ensina os saberes tradicionais.

${ }^{18}$ Chamo o livro selvagem de LivrOnça. LivrOnça é uma deglutição semiofágica dos vocábulos livro (o fora) e onça (a fera). A pele de imagens dada por Kopenawa é um livro que liberta da ilusão do livro, como comentado por Jean-Christophe Goddard (2016, p. 76). 


\section{AGRADECIMENTOS}

Agradeço pelo convívio e dedico este texto a André de Souza Silva - encantado precocemente pela colonialidade em curso do genocídio brasileiro, alargado com a pandemia do Covid-19.

\section{FINANCIAMENTO}

Este trabalho é um fruto do financiamento, a título de doutoramento, do Conselho Nacional de Desenvolvimento Científico e Tecnológico (CNPq), e, a nível de estágio de pós-doutoramento, pela Coordenação de Aperfeiçoamento de Pessoal de Nível Superior (Capes), através da bolsa do Programa Nacional de PósDoutorado, PNPD/Capes, da cota do Programa de Pós-Graduação em Ciência da Informação do Instituto Brasileiro de Informação em Ciência e Tecnologia em convênio com a Escola de Comunicação da Universidade Federal do Rio de Janeiro, PPGCI/IBICTUFRJ.

\section{REFERÊNCIAS}

AGAMBEN, Giorgio, 2011. O aberto: o homem e o animal. Lisboa, Portugal: Edições 70.

AGAMBEN, Giorgio, 2013. Opus Dei: arqueologia do ofício. São Paulo, Brasil: Boitempo.

ALIMONDA, Héctor ed., 2011. La naturaleza colonizada. Ecología política y minería em América Latina. Buenos Aires, Argentina: CLACSO.

ARISTÓTELES, 2002. Metafísica. São Paulo, Brasil: Loyola.

ARISTÓTELES, 1988. Política. Madrid, Espanha: Gredos.

AVELINO, Nildo, 2011. Foucault e a anarqueologia dos saberes. Em: Do governo dos vivos: curso no Collège de France, 1979-1980 (excertos). São Paulo, Brasil: Achiamé. p. 17-37.

BARROS, Manoel de, 2010. Poesia completa. São Paulo, Brasil: Leya.

BELTRÁN-BARRERA, Yilson J., 2019. La biocolonialidad: una genealogía decolonial. Nómadas [em linha]. 2019. vol. 50, p. 77-91. [Acesso em 24 de junho 2021]. Disponível em: http://www.scielo.org.co/pdf/noma/n50/0121-7550-noma-50-77.pdf

BLACK, Edwin, 2001. IBM e o holocausto: a aliança estratégica entre a Alemanha nazista e a mais poderosa empresa americana. Rio de Janeiro, Brasil: Campus.

BOSI, Alfredo, 1992. Dialética da colonização. São Paulo, Brasil: Companhia das Letras.

CAJIGAS-ROTUNDO, Juan Camilo, 2007. La biocolonialidad del poder. Amazonía, biodiversidade y ecocapitalismo. Em: El giro decolonial. Reflexiones para una diversidad epistémica más allá del capitalismo global. Bogotá, Colômbia: Pontificia Universidad Javeriana. p. 169-194. 
CAPURRO, Rafael, 2003. Angeletics: a Message Theory. Em: Hierarchies of communication: an inter-institutional and international symposium on aspects of communication on different scales and levels. Karlsruhe: Verlag ZKM. p. 58-71.

CAPURRO, Rafael, 1992. What is Information Science for? a philosophical reflection. Em: Conceptions of Library and Information Science: historical, empirical and theoretical perspectives. London, England: Taylor Graham. p. 82-96.

CAPURRO, Rafael, HJØRLAND, Birger, 2007. O conceito de informação. Perspectivas em Ciência da Informação [em linha]. 2007. vol. 12, no. 1, p. 148-207. [Acesso em 23 de setembro de 2015]. Disponível em:

http://portaldeperiodicos.eci.ufmg.br/index.php/pci/article/view/54/47

CASSIN, Barbara, 2005. O efeito sofístico. São Paulo, Brasil: Ed. 34.

CASSIN, Barbara, 2017. Jacques, o sofista: Lacan, logos e psicanálise. Belo Horizonte, Brasil: Autêntica.

CASSIN, Barbara, 1993. Que quer dizer: dizer alguma coisa? Discurso [em linha]. 1993. vol. 20, p. 19-39. [Acesso 29 de março 2016]. Disponível em:

https://www.revistas.usp.br/discurso/article/view/37955/40682

CASTRO-GÓMEZ, Santiago, GROSFOGUEL, Ramón, eds, 2007. El giro decolonial.

Reflexiones para una diversidad epistémica más allá del capitalismo global. Bogotá:

Pontificia Universidad Javeriana.

CESARINO, Pedro Niemeyer, 2012. A escrita e os corpos desenhados: transformações do conhecimento xamanístico entre os Marubo. Revista de Antropologia [em linha]. 2012, vol. 55, no. 1, p. 75-137. [Acesso em 29 de março 2020]. Disponível em:

https://www.revistas.usp.br/ra/article/view/47583

CLASTRES, Pierre, 1979. A sociedade contra o estado: investigações de antropologia política. Porto, Portugal: Afrontamento.

CLIFFORD, James, 1988. The predicament of culture: twentieth century ethnography, literature and art. Cambridge, USA: Harvard University Press.

CURIEL, Ochy, 2007. Crítica poscolonial desde las prácticas políticas del feminismo antirracista. Nó-madas [em linha]. 2007. no. 26, p. 92-101. [Acesso em 8 de março 2021]. Disponível em: https://www.redalyc.org/pdf/1051/105115241010.pdf

DAY, Ronald, 2005. Poststructuralism and Information Studies. Annual Review of Information Science and Technology [em linha]. 2005. vol. 39, no.1, p. 575-609. [Acesso em 24 de junho 2017]. Disponível em: https://asistdl.onlinelibrary.wiley.com/doi/abs/10.1002/aris.1440390121

DELEUZE, Gilles, 2006. Diferença e repetição. Rio de Janeiro, Brasil: Graal.

DELEUZE, Gilles, GUATTARI, Félix, 1992. O que é a filosofia? São Paulo, Brasil: Ed. 34.

DIDI-HUBERMAN, Georges, 2013. A semelhança informe, ou, o gaio saber visual segundo Georges Bataille. Rio de Janeiro, Brasil: Contraponto. 
DUSSEL, Enrique, 1993. 1492: o encobrimento do outro: a origem do mito da modernidade. Petrópolis, Brasil: Vozes.

DUSSEL, Enrique, 1996. Modernity, Eurocentrism, and Trans-Modernity: In Dialogue with Charles Taylor. Em: The Underside of Modernity: Apel, Ricoeur, Rorty, Taylor, and the Philosophy of Liberation. Atlantic Highlands: Humanities.

ESCOBAR, Arturo, 2005. Más allá del Tercer Mundo. Globalización y diferencia. Bogotá, Colômbia: Instituto Colombiano de Antropología e Historia - Universidad del Cauca.

FANON, Frantz, 1968. Os condenados da Terra. Rio de Janeiro, Brasil: Civilização brasileira.

FOUCAULT, Michel, 2011. Do governo dos vivos: curso no Collège de France, 1979-1980 (excertos). São Paulo, Brasil: Achiamé.

FLORIDI, Luciano, 2011. The philosophy of information. Oxford, England: Oxford University Press.

FROHMANN, Bernd, 2004. Documentation redux: prolegomenon to (another) philosophy of information. Library Trends [em linha]. 2004. vol. 52, no. 3, p. 387-407. [Acesso em 23 de setembro 2020]. Disponível em:

https://www.ideals.illinois.edu/handle/2142/1683

FROHMANN, Bernd, 1992. The power of images: a discourse analysis of the cognitive viewpoint. Journal of Documentation [em linha]. 1992. vol. 48, no. 4, p. 365-386. [Acesso em 3 de maio 2013]. Disponível em: https://www.emerald.com/insight/content/doi/10.1108/eb026904/full/html

GODDARD, Jean-Christophe, 2016. Notas sobre A queda do céu de Davi Kopenawa y Bruce Albert por un lector blanco. ClimaCom [em linha]. 2016. vol. 5, p. 75-83. [Acesso em 24 de junho 2021]. Disponível em:

http://climacom.mudancasclimaticas.net.br/notas-sobre-a-queda-do-ceu-de-davikopenawa-y-bruce-albert-por-un-lector-blanco/

GONZÁLEZ DE GÓMEZ, Maria Nélida, 1999. O caráter seletivo das ações de informação. Informare [em linha]. 1999. vol. 5, no.2, p. 7-31. [Acesso em 1 de agosto 2014]. Disponível em: https://ridi.ibict.br/handle/123456789/126

GONZÁLEZ DE GÓMEZ, Maria Nélida, 2002. Dos estudos sociais da informação aos estudos do social desde o ponto de vista da informação. Em: O campo da Ciência da Informação: gênese, conexões e especificidades. João Pessoa, Brasil: Ed. UFPB. p. 2548.

GONZÁLEZ DE GÓMEZ, Maria Nélida, 2012. Regime de informação: construção de um conceito. Informação \& Sociedade: Estudos [em linha]. 2012. vol. 22, no. 3, p. 43-60. [Acesso em 17 de abril de 2015]. Disponível em: https://periodicos.ufpb.br/ojs/index.php/ies/article/view/14376

GORDON, Lewis R., 2000. Existentia Africana: Understanding Africana Existential Thought. New York, USA: Routledge. 
GUÉDON, Marie-Françoise, 1984. An introduction to the Tsimshian world view and its practitioners. Em: The Tsimshian: images of the past, views for the present.

Vancouver, Canadá: University of British Columbia Press. p. 137-159.

HEIDEGGER, Martin, 2011. Conceitos fundamentais da metafísica: mundo, finitude, solidão. Rio de Janeiro, Brasil: Forense Universitária.

HEIDEGGER, Martin, 1987. Introdução à metafísica. Rio de Janeiro, Brasil: Tempo Brasileiro.

HOLBRAAD, Martin, PEDERSEN, Morten Axel, 2017. The ontological turn: an anthropological exposition. London, England: Cambridge University Press.

HOLLANDA, Chico Buarque de [CD-áudio], 1984. Brejo da Cruz. Em: Chico Buarque. Rio de Janeiro, Brasil: Polygram.

KANT, Immanuel, 2005. Antropologia de um ponto de vista pragmático. São Paulo, Brasil: Iluminuras.

KANT, Immanuel, 1986. Ideia de uma história universal de um ponto de vista cosmopolita. São Paulo, Brasil: Brasiliense.

KOJÈVE, Alexandre, 2002. Introdução à leitura de Hegel. Rio de Janeiro, Brasil: Contraponto.

KOPENAWA, Davi, ALBERT, Bruce, 2015. A queda do céu: palavras de um xamã Yanomami. São Paulo, Brasil: Companhia das Letras.

LANDER, Edgardo ed., 2000. La colonialidad del saber: eurocentrismo y ciencias sociales. Perspectivas latinoamericanas. Buenos Aires, Argentina: CLACSO.

LANDER, Edgardo, 2002. La utopía del mercado total y el poder imperial. Revista Venezolana de Economía y Ciencias Sociales [em linha]. 2002. vol. 8, no. 2, p. 51-79. [Acesso em 24 de junho 2021]. Disponível em:

https://www.redalyc.org/articulo.oa?id=17780203

LEÃO, Emmanuel Carneiro, 2010. Filosofia grega: uma introdução. Teresópolis, Brasil: Daimon editora.

LOAIZA, Estefanía Peñafiel, 2010. Cartographies 1. La crise de la dimension. Galerie Alain Gutharc [em linha]. 2010. [Acesso em 23 setembro 2020]. Disponível em: https://loop-barcelona.com/artist-video/cartographies-1-the-crisis-of-dimension/

LUGONES, María, 2008. Colonialidad y género: hacia un feminismo descolonial. Em: Género y descolonialidad. Buenos Aires, Argentina: Del Signo. p. 13-54.

MALDONADO-TORRES, Nelson, 2008. Against War: views from the Underside of Modernity. Durham, England: Duke University Press.

MALDONADO-TORRES, Nelson, 2007. Sobre la colonialidad del ser: contribuciones al desarrollo de un concepto. Em: El giro decolonial. Reflexiones para una diversidad epistémica más allá del capitalismo global. Bogotá, Colômbia: Pontificia Universidad Javeriana. p. 127-167. 
MENEZES, Vinícios Souza de, 2015. Informação, um excurso crítico-filológico. Perspectivas em Ciência da Informação [em linha]. 2015. vol. 20, no. 1, p. 3-18. [Acesso em 29 de março 2016]. Disponível em: http://portaldeperiodicos.eci.ufmg.br/index.php/pci/article/view/2074/1579

MENEZES, Vinícios Souza de, 2018b. A mulher como informe: uma maculatura desclassificada na tipografia do informar. Liinc em Revista [em linha]. 2018b. vol. 14, no. 2, p. 136-151. [Acesso em 31 de julho 2019]. Disponível em: http://revista.ibict.br/liinc/article/view/4303/3942

MENEZES, Vinícios Souza de, 2018a. O sertão da palavra informação: o informe em língua de brincar. Em: Encontro Nacional de Pesquisa em Ciência da Informação [em linha]. Londrina, PR: Ancib; UEL. 2018. [Acesso em 07 de janeiro 2019]. 19. Disponível em: https://brapci.inf.br/index.php/res/download/124822

MIGNOLO, Walter, 2017. Colonialidade: o lado mais escuro da modernidade. Revista Brasileira de Ciências Sociais [em linha]. 2017. vol. 32, no. 94, p. 1-17. [Acesso em 24 de junho 2021]. Disponível em: https://www.scielo.br/j/rbcsoc/a/nKwQNPrx5Zr3yrMjh7tCZVk/?format=pdf\&lang=pt

MIGNOLO, Walter, 1995. Decires fuera de lugar: sujetos dicentes, roles sociales y formas de inscripción. Revista de crítica literaria latino-americana [em linha]. 1995. vol. 21, no. 41, p. 9-31. [Acesso em 29 de março 2021]. Disponível em: https://www.jstor.org/stable/4530794

MIGNOLO, Walter, 2008. Desobediência epistêmica: a opção descolonial e o significado de identidade em política. Cadernos de Letras da UFF [em linha]. 2008. no. 34, p. 287-324. [Acesso em 29 de março 2021]. Disponível em: http://professor.ufop.br/sites/default/files/tatiana/files/desobediencia_epistemica_mi gnolo.pdf

MOSTAFA, Solange Puntel, 2013. Filosofia da diferença e a Ciência da Informação. Rio de Janeiro, Brasil: E-papers.

OLSON, Hope, 2002. The power to name: locating the limits of subject representation in libraries. Dordrecht, Holanda: Springer Science.

PALERMO, Zulma, 2006. Inscripción de la crítica de gênero en procesos de descolonización. Em: Cuerpo(s) de mujer: representación simbólica y crítica cultural. Córdoba: Universidad Nacional de Salta. p. 237-65.

PLATÃO, 1992. Filebo, Timeo, Critias. Madrid, Espanha: Grecos.

PLATÃO, 2017. A República. Lisboa, Portugal: Fundação Calouste Gulbenkian.

PLATÃO, 1988. Teeteto e Crátilo. Belém, Brasil: Ed. UFPA.

POMBO, Olga, 1998. Da classificação dos seres à classificação dos saberes. Revista da Biblioteca Nacional de Lisboa [em linha]. 1998. no. 2, p. 19-33. [Acesso em 1 de agosto 2015]. Disponível em:

https://webpages.ciencias.ulisboa.pt/ ommartins/investigacao/opomboclassificacao.pdf 
QUIJANO, Aníbal, 2000. Colonialidad del poder, eurocentrismo y América Latina". Em: La colonialidad del saber: eurocentrismo y ciencias sociales. Perspectivas latinoamericanas. Buenos Aires, Argentina: CLACSO. p. 203-241.

QUIJANO, Aníbal, 2007. Colonialidad del poder y clasificación social. Em: El giro decolonial. Reflexiones para una diversidad epistémica más allá del capitalismo global. Bogotá, Colômbia: Pontificia Universidad Javeriana. p. 93-126.

QUIJANO, Aníbal, 1991. Colonialidad y modernidad / racionalidad. Perú indígena [em linha]. 1991. vol. 13, no. 29, p. 11-20. [Acesso em 13 de junho 2021]. Disponível em: https://www.lavaca.org/wp-content/uploads/2016/04/quijano.pdf

QUINTERO, Pablo, FIGUEIRA, Patricia, ELIZALDE, Paz Concha, 2019. Uma breve história dos estudos decoloniais. MASP Afterall [em linha]. 2019. p. 1-11. [Acesso em 13 de junho 2021]. Disponível em: https://masp.org.br/uploads/temp/tempQE1LhobgtE4MbKZhc8Jv.pdf

SEEGER, Anthony, DA MATTA, Roberto, CASTRO, Eduardo Viveiros de, 1979. A construção da pessoa nas sociedades indígenas brasileiras. Boletim do Museu Nacional [em linha]. 1979. vol. 32, p. 2-19. [Acesso em 23 de setembro 2016]. Disponível em: http://www.ppgasmnufri.com/uploads/2/7/2/8/27281669/boletim_do_museu_nacional_32.pdf

SEGATO, Rita, 2010. Gênero y colonialidad: en busca de claves de lectura y de un vocabulário estratégico descolonial. Em: La cuestión descolonial. Lima: Universidad Ricardo Palma.

STRATHERN, Marilyn, 2006. O gênero da dádiva: problemas com as mulheres e problemas com a sociedade na Melanésia. Campinas, Brasil: Unicamp.

THESAURUS linguae latinae, 1934. Leipzig, Alemanha: editvs ivssv et avctoritate consilii ab academiis societatibvsqve diversarvm nationvm electi.

VALENTIM, Marco Antônio, 2018. Extramundanidade e sobrenatureza: ensaios de ontologia infundamental. Florianópolis, Brasil: Cultura e Barbárie.

VIVEIROS DE CASTRO, Eduardo, 2017. A inconstância da alma selvagem e outros ensaios de antropologia. São Paulo: Cosac Naify.

VIVEIROS DE CASTRO, Eduardo, 2018. Metafísicas canibais: elementos para uma antropologia pós-estrutural. São Paulo, Brasil: Ubu.

VIVEIROS DE CASTRO, Eduardo, 2002. O nativo relativo. Mana [em linha]. 2002. vol. 8, no. 1, p. 113-148. [Acesso em 07 de janeiro 2017]. Disponível em: https://www.scielo.br/j/mana/a/ZcqxxhqhZk9936mxW5GRrhq/?lang=pt

VIVEIROS DE CASTRO, Eduardo, 2012. "Transformação" na Antropologia, transformação da "Antropologia”. Mana [em linha]. 2012. vol. 18, no. 1, p. 151-171. [Acesso em 23 de setembro de 2015]. Disponível em: https://www.scielo.br/j/mana/a/GNFYDzH8dngXWW4SfgVjSpH/abstract/?lang=pt 
WARBURG, Aby, 2013. A renovação da Antiguidade pagã: contribuições científicoculturais para a história do Renascimento europeu. Rio de Janeiro, Brasil:

Contraponto.

WRIGHT, Alex, 2014. Cataloging the world: Paul Otlet and the birth of the information age. New York, USA: Oxford University Press. 